Open Access

\title{
A mathematical model of $\mathrm{CO}_{2}, \mathrm{O}_{2}$ and $\mathrm{N}_{2}$ exchange during venovenous extracorporeal membrane oxygenation
}

\author{
Christopher John Joyce ${ }^{1,2^{*}}$ (D) Kiran Shekar ${ }^{1,3,5}$ and David Andrew Cook ${ }^{1,2,4}$
}

\author{
* Correspondence: \\ chris.joyce@health.qld.gov.au \\ ${ }^{1}$ Discipline of Anaesthesiology \\ Critical Care, University of \\ Queensland, Ned Hanlon Building, \\ Royal Brisbane and Women's \\ Hospital, Herston, QLD 4006, \\ Australia \\ ${ }^{2}$ Department of Intensive Care, \\ Princess Alexandra Hospital, 199 \\ Ipswich Rd, Woolloongabba, QLD \\ 4102, Australia \\ Full list of author information is \\ available at the end of the article
}

\begin{abstract}
Background: Venovenous extracorporeal membrane oxygenation (Vv-ECMO) is an effective treatment for severe respiratory failure. The interaction between the cardiorespiratory system and the oxygenator can be explored with mathematical models. Understanding the physiology will help the clinician optimise therapy. As others have examined $\mathrm{O}_{2}$ exchange, the main focus of this study was on $\mathrm{CO}_{2}$ exchange.

Methods: A model of the cardiorespiratory system during vv-ECMO was developed, incorporating $\mathrm{O}_{2}, \mathrm{CO}_{2}$ and $\mathrm{N}_{2}$ exchange in both the lung and the oxygenator. We modelled lungs with shunt fractions varying from 0 to 1, covering the plausible range from normal lung to severe acute respiratory distress syndrome. The effects on $\mathrm{P}_{\mathrm{a}} \mathrm{CO}_{2}$ of varying the input parameters for the cardiorespiratory system and for the oxygenator were examined.
\end{abstract}

Results: $\mathrm{P}_{\mathrm{a}} \mathrm{CO}_{2}$ increased as the shunt fraction in the lung and metabolic $\mathrm{CO}_{2}$ production rose. Changes in haemoglobin and $\mathrm{F}_{1} \mathrm{O}_{2}$ had minimal effect on $\mathrm{P}_{\mathrm{a}} \mathrm{CO}_{2}$. The effect of cardiac output on $\mathrm{P}_{\mathrm{a}} \mathrm{CO}_{2}$ was variable, depending on the shunt fraction in the lung. $\mathrm{P}_{\mathrm{a}} \mathrm{CO}_{2}$ decreased as extracorporeal circuit blood flow was increased, but the changes were relatively small in the range used clinically for $\mathrm{v}$-ECMO of $>2 \mathrm{l} / \mathrm{min} . \mathrm{P}_{\mathrm{a}} \mathrm{CO}_{2}$ decreased as gas flow to the oxygenator rose and increased with recirculation. The oxygen fraction of gas flow to the oxygenator had minimal effect on $\mathrm{P}_{\mathrm{a}} \mathrm{CO}_{2}$.

Conclusions: This mathematical model of gas exchange during $v v-E C M O$ found that the main determinants of $\mathrm{P}_{\mathrm{a}} \mathrm{CO}_{2}$ during $\mathrm{vv}$-ECMO were pulmonary shunt fraction, metabolic $\mathrm{CO}_{2}$ production, gas flow to the oxygenator and extracorporeal circuit recirculation.

Keywords: Extracorporeal membrane oxygenation, ECMO, Venovenous ECMO, Extracorporeal $\mathrm{CO}_{2}$ removal, Gas exchange, Mathematical model, Respiratory failure, Acute respiratory distress syndrome

\section{Background}

The use of extracorporeal respiratory support to manage severe respiratory failure is increasing [1]. When oxygenation is adequate and the main problem is hypercapnia, extracorporeal $\mathrm{CO}_{2}$ removal may be used, but if oxygenation is inadequate then venovenous extracorporeal membrane oxygenation (vv-ECMO) is required. Management of these patients requires a thorough understanding of vv-ECMO physiology, which is a 
complex physiological interaction between the cardio-respiratory system and the vv-ECMO circuit [2]. The main goal of vv-ECMO is to avoid hypoxia, but with consideration of minimising the important adverse effects associated with hyperoxia [3], hypercapnia and hypocapnia [4], all of which may occur during vv-ECMO. Understanding the factors that determine $\mathrm{O}_{2}$ exchange and $\mathrm{CO}_{2}$ exchange during vv-ECMO and safely manipulating the complex physiology is vital.

Clinical studies have examined $\mathrm{O}_{2}$ and $\mathrm{CO}_{2}$ exchange during vv-ECMO for respiratory failure [5]. Circuit blood flow was the main determinant of arterial oxygenation, while the sweep gas flow through the oxygenator was the main determinant of $\mathrm{CO}_{2}$ elimination. While clinical studies are important in exploring vv-ECMO physiology, mathematical modelling is an essential tool to extend understanding of physiological systems [6]. It enables study of dynamic scenarios that cannot be examined in clinical studies due to ethical considerations, the inability to isolate the effects of changing a single parameter due to reflex responses and the logistics of clinical studies in a limited number of patients.

Hollow fibre membrane oxygenators have become the standard of care for vv-ECMO [7]. Mathematical models of $\mathrm{O}_{2}$ and $\mathrm{CO}_{2}$ exchange in these devices have been developed $[8,9]$, and provide useful information about how they behave. However, these models only examine oxygenator function, and do not consider its interaction with the cardio-respiratory system, so their clinical utility is limited. The determinants of oxygenation during vv-ECMO have been explored with mathematical models that incorporate both an oxygenator and the cardiorespiratory physiology and their findings fit well with clinical studies $[10,11]$, but these models have not incorporated $\mathrm{CO}_{2}$ exchange.

The purpose of this work was to develop a new model of the cardiorespiratory system during vv-ECMO, which incorporated $\mathrm{O}_{2}, \mathrm{CO}_{2}$ and $\mathrm{N}_{2}$ exchange, in both the oxygenator and the lung. It was used to assess the effects of a various physiological parameters and vv-ECMO circuit settings on vv-ECMO physiology.

\section{Methods}

\section{Model description}

A simple model of the cardiorespiratory system during vv-ECMO (Fig. 1) was implemented using Matlab R2017a (Mathworks, USA). A more detailed description of the model, including the mathematical equations underlying it, is given in the Additional file 1.

A three-compartment model of the lung, based on Riley and Cournard's model [12], was used. One compartment was "shunt", with perfusion but no ventilation, and did not participate in gas exchange. The second compartment was the "ideal lung" compartment, in which pulmonary gas exchange occurred. Diffusion equilibrium was assumed. The third compartment was "dead space", with ventilation but no perfusion, and did not participate in gas exchange. Kelman's subroutines [13-15] were used to calculate contents from partial pressures. The equations for gas exchange were based on those used by West and Wagner [16]. The model examines the system at equilibrium. Because of the presence of the oxygenator, $\mathrm{N}_{2}$ exchange across the lung was not assumed to be zero. Expired minute ventilation $\left(\dot{V}_{E}\right)$ and expired alveolar ventilation $\left(\dot{V}_{A}\right)$ were expressed at body temperature and pressure saturated (BTPS), and contents of gases dissolved in blood were expressed as standard temperature and pressure dry (STPD). 




Fig. 1 Outline of the ECMO model. Blood flow shown in blue. $\dot{Q}_{T}$ is cardiac output, $\dot{Q}_{L}$ is blood flow to lung compartment, $\dot{Q}_{S}$ is pulmonary shunt blood flow, $\dot{Q}_{E C}$ is blood flow to the extracorporeal blood circuit, $\dot{Q}_{o x y}$ is blood flow to the ideal oxygenator compartment that participates in gas exchange, while $\dot{Q}_{S E C}$ is shunt blood flow that does not participate in gas exchange. $\dot{Q}_{E C}$ includes both recirculated blood flow $\left(\dot{Q}_{R C}\right)$ and part of the "mixed venous" blood flow from the tissues. Gas flows shown in green. $\dot{V}_{A}$ is alveolar ventilation, $\dot{V}_{D}$ is dead space ventilation, $\dot{V}_{E}$ is expired minute ventilation, $\dot{V}_{\text {SWEEP }}$ is sweep gas flow to the oxygenator, oxygenator and lung are modelled as ideal lung compartments. Tissues consume $\mathrm{O}_{2}$ and produce $\mathrm{CO}_{2}$. "Arterial" blood perfuses the tissues, and "Mixed Venous" blood drains from the tissues. "Pulmonary Arterial" blood is a mixture of blood that has passed through the extracorporeal circuit, and blood that has not

The oxygenator was modelled in a similar way to the lung, except that the shunt fraction and the dead space were set to zero, and recirculation was incorporated. Diffusion equilibrium was assumed in the "ideal oxygenator" compartment. Sweep gas flow to the oxygenator $\left(\dot{V}_{\text {SWEEP }}\right)$ was expressed at ambient temperature $\left(24{ }^{\circ} \mathrm{C}\right)$ and pressure $(760 \mathrm{mmHg})$ dry (ATPD).

Input parameters required by the model are total cardiac output in $1 / \min \left(\dot{Q}_{T}\right)$, pulmonary shunt fraction $\left(\frac{\dot{Q}_{S}}{\dot{Q}_{T}}\right)$, inspired oxygen fraction to the lung $\left(\mathrm{F}_{\mathrm{I}} \mathrm{O}_{2}\right)$, blood flow to the extracorporeal circuit in $1 / \min \left(\dot{Q}_{E C}\right)$, fraction of $\dot{Q}_{E C}$ that is recirculated to the extracorporeal circuit $\left(\frac{\dot{Q}_{R C}}{\dot{Q}_{E C}}\right)$, shunt fraction of the extracorporeal circuit $\left(\frac{\dot{Q}_{S E C}}{\dot{Q}_{E C}}\right)$, oxygen fraction of gas flowing to the oxygenator $\left(F_{O X Y} \mathrm{O}_{2}\right)$, sweep gas flow to the oxygenator in 1/min ATPD ( $\left.\dot{V}_{\text {SWEEP }}\right)$, haemoglobin in $\mathrm{g} / \mathrm{dl}(H b)$, body temperature in degrees Celsius (temp), a factor that accounts for shifts in the $\mathrm{O}_{2}$ dissociation curve due to changes in 2,3 di-phosphoglycerate (DP50), oxygen consumption in ml STPD/ $\min \left(\dot{V} \mathrm{O}_{2}\right)$ and respiratory quotient (RQ). The base excess was assumed to be zero. Haematocrit (Hct) was calculated as $3 \times \mathrm{Hb} / 100$.

The program uses initial trial values of $\mathrm{P}_{\mathrm{pa}} \mathrm{O}_{2}, \mathrm{P}_{\mathrm{pa}} \mathrm{CO}_{2}$ and $\mathrm{P}_{\mathrm{pa}} \mathrm{N}_{2}$ (gas partial pressures in pulmonary arterial blood). The principle of conservation of mass for $\mathrm{O}_{2}, \mathrm{CO}_{2}$ and $\mathrm{N}_{2}$ allows the partial pressures and contents in each of the domains of the model to be calculated sequentially, including calculated estimates of $\mathrm{P}_{\mathrm{pa}} \mathrm{O}_{2}, \mathrm{P}_{\mathrm{pa}} \mathrm{CO}_{2}$ and $\mathrm{P}_{\mathrm{pa}} \mathrm{N}_{2}$, that follow from the trial values. The mathematical problem is considered solved when trial values of $\mathrm{P}_{\mathrm{pa}} \mathrm{O}_{2}, \mathrm{P}_{\mathrm{pa}} \mathrm{CO}_{2}$ and $\mathrm{P}_{\mathrm{pa}} \mathrm{N}_{2}$ have been found that generate calculated estimates that are all 
within $0.001 \mathrm{mmHg}$ of the trial values. The problem is essentially that of finding the root in three dimensions of a system of non-linear equations which is solved using the false position method, in three dimensions.

To examine the physiological interactions between vv-ECMO settings and the cardiorespiratory system during vv-ECMO, the lung in the model was set up to mimic a patient with varying severity of acute respiratory distress syndrome (ARDS). The approach taken was based on Gattonini's concept of the ARDS lung consisting of a "baby lung" with near normal specific compliance and dependent areas of atelectasis the size of which corresponds to the shunt fraction [17]. Contemporary approaches to mechanical ventilation limit the distending pressure the lung is exposed to, so $\dot{V}_{A}$ falls, as the amount of atelectasis and corresponding pulmonary shunt fraction increases. This was modelled by keeping the ventilation perfusion ratio of the baby lung $\left(\frac{\dot{V}_{A}}{\dot{Q}_{L}}\right)$ at a constant value, mimicking the clinical situation where $\dot{V}_{A}$ falls and $\frac{V_{D}}{V_{T}}$ rises with worsening ARDS. To achieve this, $\dot{V}_{D}$ was maintained at a constant value, and $\dot{V}_{E}$ varied to achieve the desired value of $\frac{\dot{V}_{A}}{\dot{Q}_{L}}$.

The $\dot{V}_{E}$ required to give a $\mathrm{P}_{\mathrm{a}} \mathrm{CO}_{2}$ of $40 \mathrm{mmHg}$, when the lung had no shunt and $\frac{V_{D}}{V_{T}}$ was 0.3 , was initially calculated. In the standard ARDS lung, this value of $\dot{V}_{E}$ was $6.157 \mathrm{l} / \mathrm{min}, \dot{V}_{D}$ was $1.847 \mathrm{l} / \mathrm{min}$ and the corresponding ventilation-perfusion ratio of perfused lung $\left(\frac{\dot{V}_{A}}{\dot{Q}_{L}}\right)$ was 0.7183 . In keeping with the baby lung concept, $\frac{\dot{V}_{A}}{\dot{Q}_{L}}$ was maintained constant at 0.7183 , while $\frac{\dot{Q}_{S}}{\dot{Q}_{T}}$ was varied between 0.5 and $1 . \dot{V}_{D}$ was maintained constant at $1.847 \mathrm{l} / \mathrm{min}$ allowing the $\frac{V_{D}}{V_{T}}$ and $\dot{V}_{E}$ for any given scenario to be calculated. Total atelectasis of the lung is common during lung protective ventilation on vv-ECMO for severe ARDS, and this is represented in the model when $\frac{\dot{Q}_{S}}{\dot{Q}_{T}}$ is 1.0 .

Where the model would require $C_{\bar{v}} \mathrm{O}_{2}<0$ for a solution, this was considered physiological untenable and the program returned an error warning and no results were output. Results are presented with the upper and lower values on the $x$ axis scale set to encompass the $x$ axis values tested, so missing data are due to an untenable result.

\section{Scenarios examined with the model}

First, a validation was performed by comparing the findings of the model about oxygenation to those of Zanella's model [11]. Input parameters were set to those in Zanella's paper, and $\dot{V}_{\text {SWEEP }}$ adjusted to obtain $\mathrm{P}_{\mathrm{a}} \mathrm{CO}_{2}$ of $40 \mathrm{mmHg}$. The same output parameters were examined, enabling validation by reproducing the graphs from Zanella's paper.

For all subsequent modelling, unless otherwise stated, $\mathrm{F}_{\mathrm{I}} \mathrm{O}_{2} 1.0, F_{O X Y} \mathrm{O}_{2} 1.0, \dot{Q}_{T} 6 \mathrm{l} / \mathrm{min}$, $\dot{V} \mathrm{O}_{2} 250 \mathrm{ml} / \mathrm{min} \mathrm{STPD}, \mathrm{Hb} 10 \mathrm{~g} / \mathrm{dl}$, DP50 0, $\frac{\dot{Q}_{S E C}}{\dot{Q}_{E C}} 0, \frac{\dot{Q}_{R C}}{\dot{Q}_{E C}}$, temp $37{ }^{\circ} \mathrm{C}, R Q 0.8$ and $\dot{V}_{D}$ $1.847 \mathrm{l} / \mathrm{min}$ were used as input parameters. $\dot{Q}_{E C}, \frac{\dot{Q}_{S}}{\dot{Q}_{T}}$ and $\dot{V}_{\text {SWEEP }}$ were set and varied as 
required for the scenario being simulated. The derived parameters $\frac{\dot{V}_{A}}{\dot{Q}_{L}}$ and $\dot{V}_{D}$ were maintained constant at 0.7183 and $1.847 \mathrm{l} / \mathrm{min}$. The output of the program for each scenario was written to a .csv file (these have been combined into the Additional file 2).

Second, the effect on oxygenation of different approaches to managing $\dot{V}_{\text {SWEEP }}$ was investigated. The standard ARDS lung was used with $\frac{\dot{Q}_{S}}{\dot{Q}_{T}}$ ranging from 0.5 to 1.0. Three ways in which $\dot{V}_{\text {SWEEP }}$ could be managed as $\dot{Q}_{E C}$ was varied were examined: (a) $\dot{V}_{\text {SWEEP }}$ adjusted to maintain arterial $\mathrm{P}_{\mathrm{a}} \mathrm{CO}_{2}=40 \mathrm{mmHg}$; (b) $\dot{V}_{\text {SWEEP }}$ fixed at 2.5, 5, 10 and $15 \mathrm{l} / \mathrm{min}$; and (c) $\dot{V}_{\text {SWEEP }}$ adjusted to maintain $\frac{\dot{V}_{\text {SWEEP }}}{\dot{Q}_{E C}}$ constant.

Third, the factors that affect $\mathrm{P}_{\mathrm{a}} \mathrm{CO}_{2}$ in the patient on vv-ECMO were studied using the standard ARDS lung.

Finally, the sensitivity of the output from the model to the choice of parameters set in the model lung was examined. The standard ARDS lung model was chosen to mimic a lung where the shunt fraction parallels the development of atelectactic lung, which is perfused but unventilated. $\dot{V}_{A}$ is proportional to the amount of non-atelectatic lung.

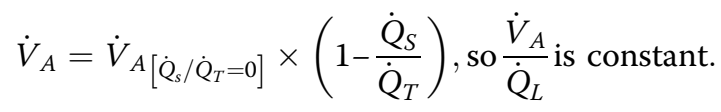

The other extreme is a lung in which $\dot{V}_{A}$ remains constant regardless of $\frac{\dot{Q}_{S}}{\dot{Q}_{T}}$ (constant $\dot{V}_{A}$ model). $\frac{\dot{V}_{A}}{\dot{Q}_{L}}=\frac{\dot{V}_{A}}{\dot{Q}_{T}\left(1-\frac{\dot{Q}_{S}}{\dot{Q}_{T}}\right)}$. The constant $\dot{V}_{A}$ model was modelled with $\dot{V}_{A}$ maintained constant at $4.310 \mathrm{l} / \mathrm{min}$. This was the $\dot{V}_{A}$ that gave $\mathrm{P}_{\mathrm{a}} \mathrm{CO}_{2}$ of $40 \mathrm{mmHg}$ when the lung had no shunt. The effect on $\mathrm{P}_{\mathrm{a}} \mathrm{CO}_{2}$ of changing $\dot{Q}_{E C}$, over a range of $\frac{\dot{Q}_{S}}{\dot{Q}_{T}}$, was examined with both the standard ARDS lung and the constant $\dot{V}_{A}$ model, and the results of the two models compared.

\section{Results}

First, when the validation was performed with input parameters similar to Zanella's model [11], the model produced almost identical graphical output (see the Additional file 3). This provided independent verification of Zanella's model, and validation of the more complex mathematical approach that we have taken.

Second, when the effect on oxygenation of different approaches to managing $\dot{V}_{\text {SWEEP }}$ was investigated, the way in which $\dot{V}_{\text {SWEEP }}$ was managed as $\dot{Q}_{E C}$ varied had minimal effect on oxygenation (Fig. 2 and Additional file 4: Figure S1). As $\dot{Q}_{E C}$ increased, $\mathrm{S}_{\mathrm{a}} \mathrm{O}_{2}$ and $\mathrm{S}_{\overline{\mathrm{v}}} \mathrm{O}_{2}$ rose. The higher the $\frac{\dot{Q}_{S}}{\dot{Q}_{T}}$, the higher the $\dot{Q}_{E C}$ to achieve "acceptable" values of $\mathrm{S}_{\mathrm{a}} \mathrm{O}_{2}>85 \%$ and $\mathrm{S}_{\overline{\mathrm{V}}} \mathrm{O}_{2}>60 \%$. For all these scenarios, at any given $\dot{Q}_{E C}$ and $\frac{\dot{Q}_{s}}{\dot{Q}_{T}}$, the output $\mathrm{S}_{\mathrm{a}} \mathrm{O}_{2}$ and $\mathrm{S}_{\overline{\mathrm{V}}}$ $\mathrm{O}_{2}$ did not differ by more than 1.5 (\% oxygen saturation) from the $\mathrm{S}_{\mathrm{a}} \mathrm{O}_{2}$ and $\mathrm{S}_{\overline{\mathrm{V}}} \mathrm{O}_{2}$ output in the simulation that held $\mathrm{P}_{\mathrm{a}} \mathrm{CO}_{2}$ constant at $40 \mathrm{mmHg}$. Output $\mathrm{C}_{\mathrm{a}} \mathrm{O}_{2}$ did not differ by 


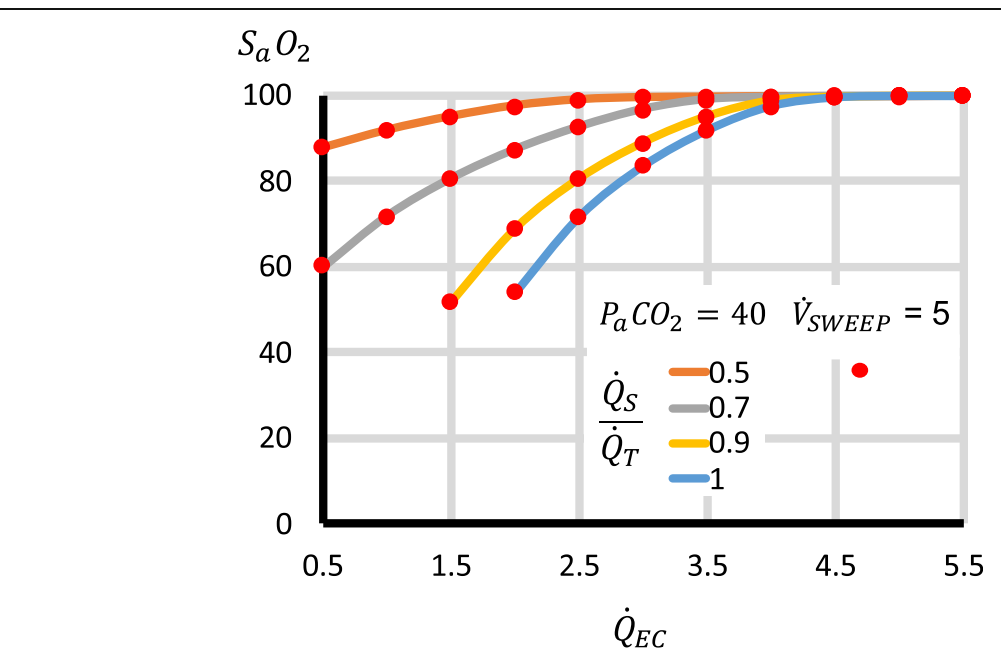

Fig. 2 Effect on $\mathrm{S}_{a} \mathrm{O}_{2}$ of different approaches to managing $\dot{V}_{\text {SwEep }}$. Results for when $\mathrm{P}_{\mathrm{a}} \mathrm{CO}_{2}$ is held constant at $40 \mathrm{mmHg}$ by varying $\dot{V}_{\text {SWEEP }}$ (continuous lines) compared to when $\dot{V}_{\text {SWEEP }}$ is held constant at $5 \mathrm{l} / \mathrm{min}$ (data points as red markers). As $\dot{Q}_{E C}$ increases, $S_{a} \mathrm{O}_{2}$ rises. The higher the $\frac{\dot{Q}_{S}}{\dot{Q}_{T}}$, the higher the $\dot{Q}_{E C}$ required to achieve "acceptable" values of $\mathrm{S}_{a} \mathrm{O}_{2}>85 \%$. The red dots of fixed $\dot{V}_{\text {SWEEP }}=5 \mathrm{l} / \mathrm{min}$ match the curves of variable $\dot{V}_{\text {SWEEP }}$ (fixed $\mathrm{P}_{\mathrm{a}} \mathrm{CO}_{2}$ ), demonstrating that the approach taken to managing $\dot{V}_{\text {SWEEP }}$ has minimal effect on $\mathrm{S}_{\mathrm{a}} \mathrm{O}_{2}$

more than 0.2 (ml STPD/100 ml blood). The biggest difference in $\mathrm{P}_{\mathrm{a}} \mathrm{O}_{2}$ was $19 \mathrm{mmHg}$, which occurred at high $\dot{Q}_{E C}$ when $\mathrm{P}_{\mathrm{a}} \mathrm{O}_{2}$ was $>500 \mathrm{mmHg}$.

Third, the factors with important effects on $\mathrm{P}_{\mathrm{a}} \mathrm{CO}_{2}$ were $\frac{\dot{Q}_{S}}{\dot{Q}_{T}}, \dot{Q}_{E C}, \dot{V}_{\text {SWEEP }}, \dot{V} \mathrm{CO}_{2}$ and $\frac{\dot{Q}_{R C}}{\dot{Q}_{E C}}$. Higher $\frac{\dot{Q}_{S}}{\dot{Q}_{T}}$ increased $\mathrm{P}_{\mathrm{a}} \mathrm{CO}_{2}$ (Fig. 3). Increases in $\dot{Q}_{E C}$ reduced $\mathrm{P}_{\mathrm{a}} \mathrm{CO}_{2}$, but for $\dot{Q}_{E C}>21 / \mathrm{min}$, the changes were relatively small (Fig. 3), though they became larger

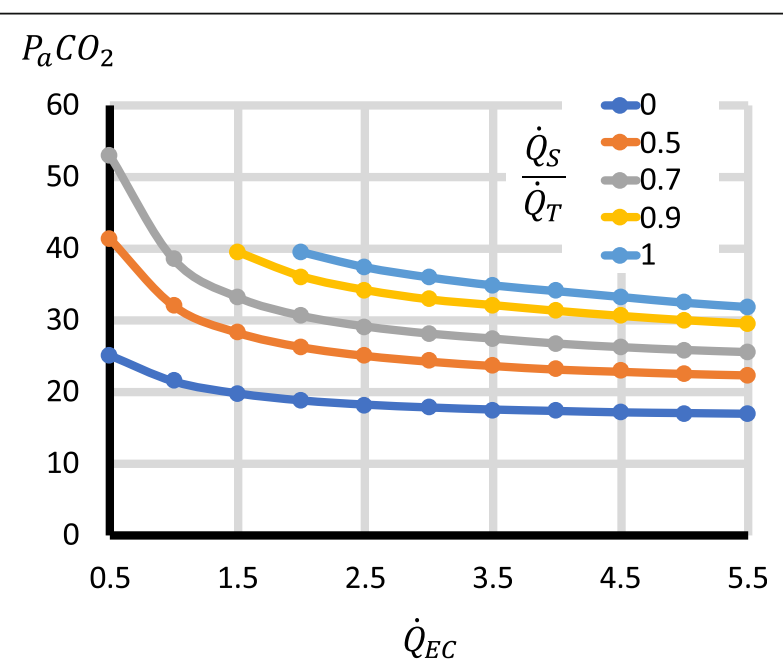

Fig. 3 Effect on $\mathrm{P}_{\mathrm{a}} \mathrm{CO}_{2}$ of $\dot{\mathrm{Q}}_{\mathrm{EC}}$ and $\frac{\dot{Q}_{S}}{\dot{Q}_{T}} \cdot \dot{V}_{\text {SWEEP }}$ is held constant at $5 \mathrm{l} / \mathrm{min}$. As $\dot{Q}_{E C}$ is reduced, $\mathrm{P}_{\mathrm{a}} \mathrm{CO}_{2}$ rises, but at $>2 \mathrm{l} / \mathrm{min}$ the curve is relatively flat, particularly when $\frac{\dot{Q}_{S}}{\dot{Q}_{T}}$ is low. $P_{\mathrm{a}} \mathrm{CO}_{2}$ rises as $\frac{\dot{Q}_{S}}{\dot{Q}_{T}}$ increases 
with high $\dot{V} \mathrm{CO}_{2}$ (Fig. 4). Increases in $\dot{V}_{\text {SWEEP }}$ reduced $\mathrm{P}_{\mathrm{a}} \mathrm{CO}_{2}$ (Fig. 5). The $\dot{V}_{\text {SWEEP }}$ required to maintain $\mathrm{P}_{\mathrm{a}} \mathrm{CO}_{2}$ at $40 \mathrm{mmHg}$ fell as $\dot{Q}_{E C}$ increased, but for $\dot{Q}_{E C}>2 \mathrm{l} / \mathrm{min}$, the changes were relatively small (Fig. 6). There was a linear increase in $\mathrm{P}_{\mathrm{a}} \mathrm{CO}_{2}$ with $\dot{V} \mathrm{CO}_{2}$ (Fig. 4). $\mathrm{P}_{\mathrm{a}} \mathrm{CO}_{2}$ rose and $\mathrm{S}_{\mathrm{a}} \mathrm{O}_{2}$ fell as recirculation increased (Fig. 7). At high $\frac{\dot{Q}_{s}}{\dot{Q}_{T}}$, when the recirculation was high, $\mathrm{S}_{\mathrm{a}} \mathrm{O}_{2}$ fell to physiological untenable levels (Additional file 5: Figure S2).

Changes in $\mathrm{Hb}, \mathrm{F}_{\mathrm{I}} \mathrm{O}_{2}$ and $\mathrm{F}_{\mathrm{OXY}} \mathrm{O}_{2}$, had minimal effect on $\mathrm{P}_{\mathrm{a}} \mathrm{CO}_{2}$, despite the important effects these parameters have on oxygenation (Additional file 6: Figure S3, Additional file 7: Figure S4, and Additional file 8: Figure S5). The effect of $\dot{Q}_{T}$ on $\mathrm{P}_{\mathrm{a}} \mathrm{CO}_{2}$ was variable, depending on the shunt fraction (Additional file 9: Figure S6).

Finally, the sensitivity of the model to the parameters set in the model lung was studied. With both the constant $\dot{V}_{A}$ lung model and the standard ARDS lung model, increases in $\dot{Q}_{E C}$ produced a fall in $\mathrm{P}_{\mathrm{a}} \mathrm{CO}_{2}$, but for $\dot{Q}_{E C}>2 \mathrm{l} / \mathrm{min}$, the changes were relatively small. The results for $\frac{\dot{Q}_{S}}{\dot{Q}_{T}}$ of 0 , and for $\frac{\dot{Q}_{S}}{\dot{Q}_{T}}$ of 1 were identical, but the curves for $\frac{\dot{Q}_{S}}{\dot{Q}_{T}}$ between these values were in different positions (Additional file 10: Figure S7).

\section{Discussion}

Previous mathematical models of gas exchange during vv-ECMO have only examined $\mathrm{O}_{2}$ exchange [10,11], or made unrealistic assumptions about $\mathrm{CO}_{2}$ exchange [18]. They are unable to assess the determinants of $\mathrm{CO}_{2}$ exchange. To overcome this limitation, a mathematical model of gas exchange during vv-ECMO, that incorporated $\mathrm{O}_{2}, \mathrm{CO}_{2}$ and $\mathrm{N}_{2}$ exchange, was developed. The effect of input physiological parameters and vv-ECMO circuit settings on oxygenation was compared to the findings of Zanella's model [11], which only included $\mathrm{O}_{2}$ exchange. Our model closely reproduced the outputs of Zanella's model and can be reviewed in the Additional files. This provides validation of the more complex mathematical approach presented here. This validation is limited to

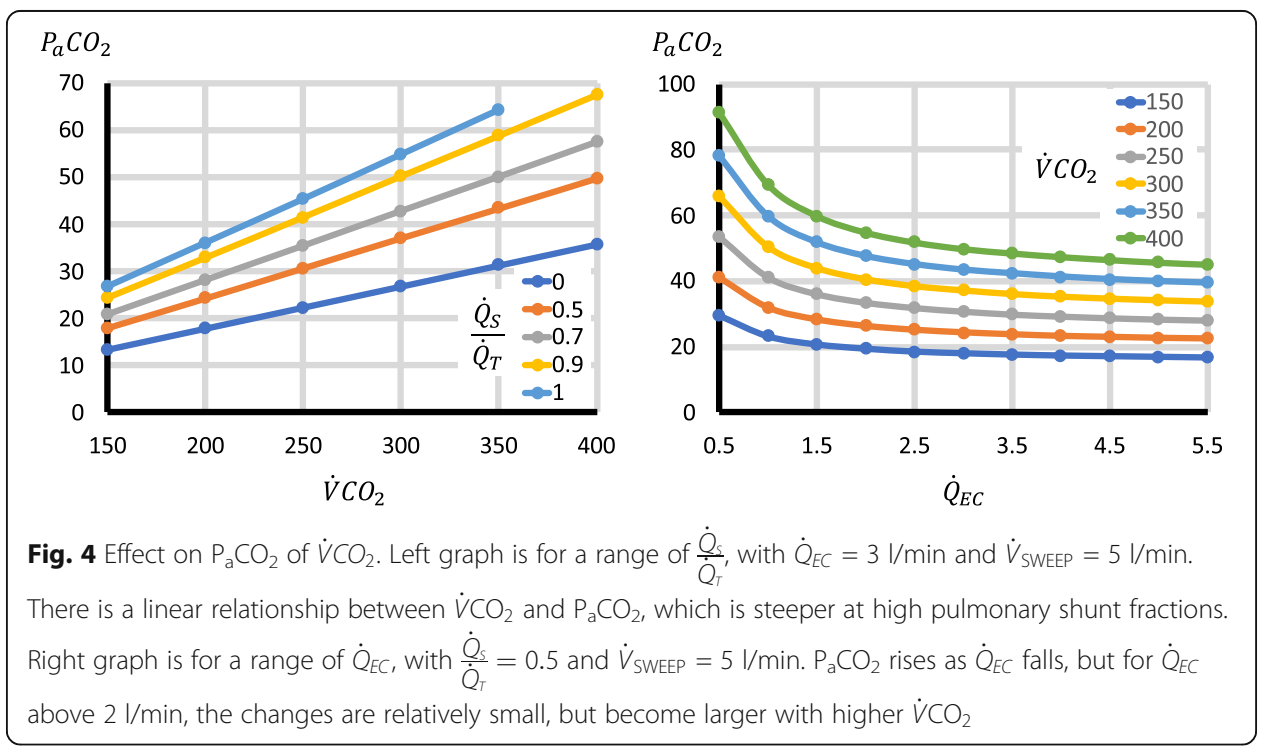




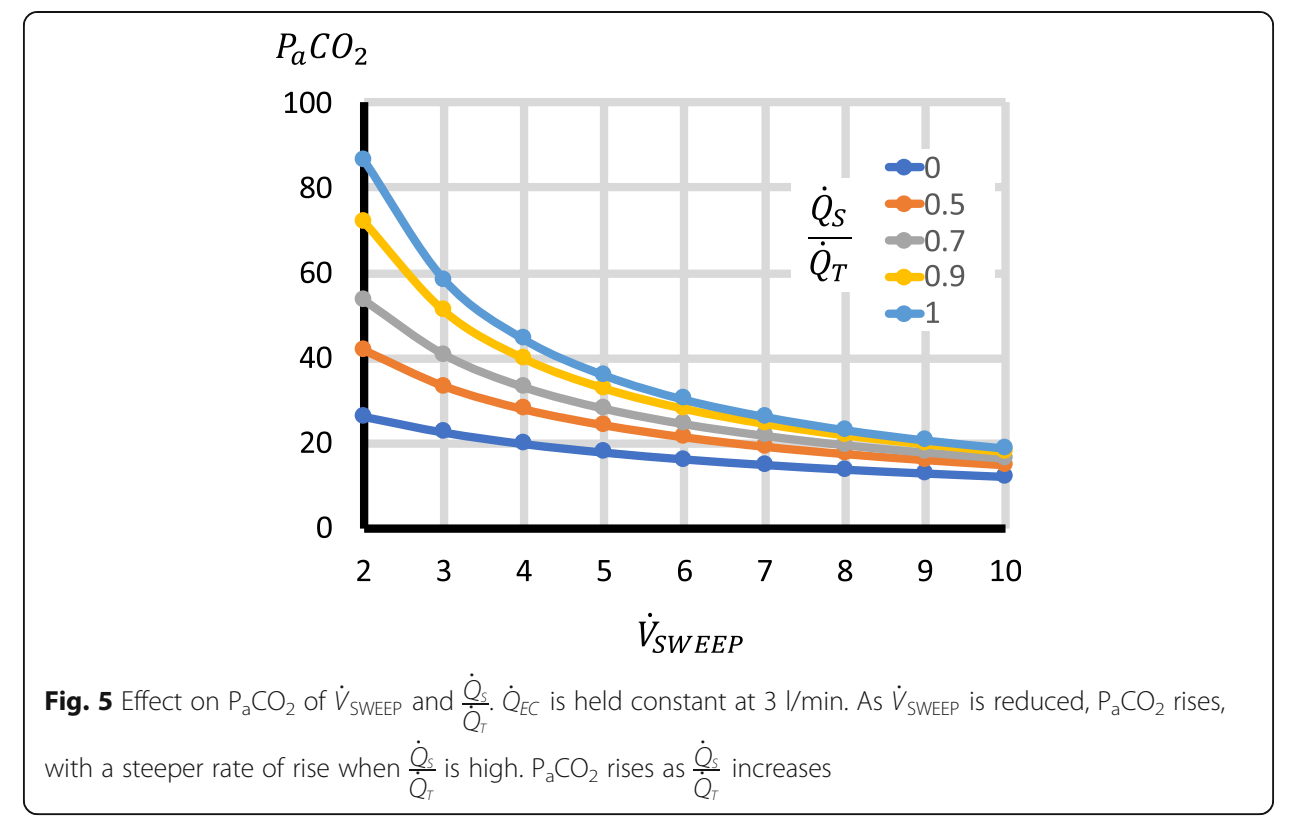

the effects on oxygenation, as Zanella did not examine $\mathrm{CO}_{2}$ exchange. Zanella's simpler approach would be preferred if only $\mathrm{O}_{2}$ exchange was of interest, but it cannot be used if $\mathrm{CO}_{2}$ exchange is to be examined.

The major advantage of this model over previous models is the incorporation of $\mathrm{CO}_{2}$ exchange, which allows the effect of input physiological parameters and vv-ECMO circuit settings on $\mathrm{P}_{\mathrm{a}} \mathrm{CO}_{2}$ to be assessed. The key finding of our paper is that providing $\dot{Q}_{E C} \geq 2 \mathrm{l} / \mathrm{min}$, the major determinants of $\mathrm{P}_{\mathrm{a}} \mathrm{CO}_{2}$ are $\dot{V} \mathrm{CO}_{2}, \dot{V}_{\text {SWEEP }}$ and $\frac{\dot{Q}_{S}}{\dot{Q}_{T}}$. This

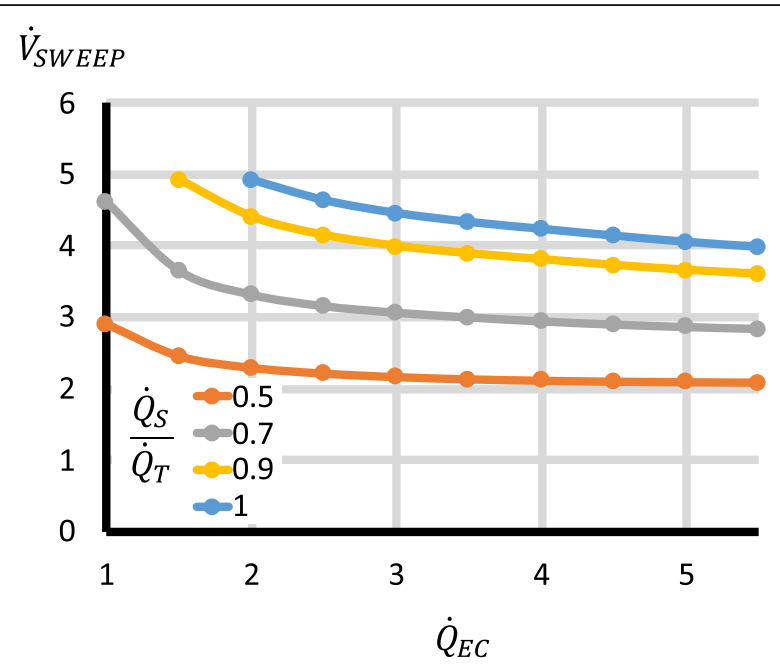

Fig. 6 Effect on the $\dot{V}_{S W E E P}$ required to maintain $P_{a} C_{2}$ at $40 \mathrm{mmHg}$, of $\dot{Q}_{E C}$ and $\frac{\dot{Q}_{S}}{\dot{Q}_{T}}$. As $\dot{Q}_{E C}$ is reduced, the required $\dot{V}_{\text {SWEEP }}$ rises, though the rise is small until $\dot{Q}_{E C}$ is $<2 \mathrm{l} / \mathrm{min}$. The required $\dot{V}_{S W E E P}$ rises as $\frac{\dot{Q}_{S}}{\dot{Q}_{T}}$ rises 

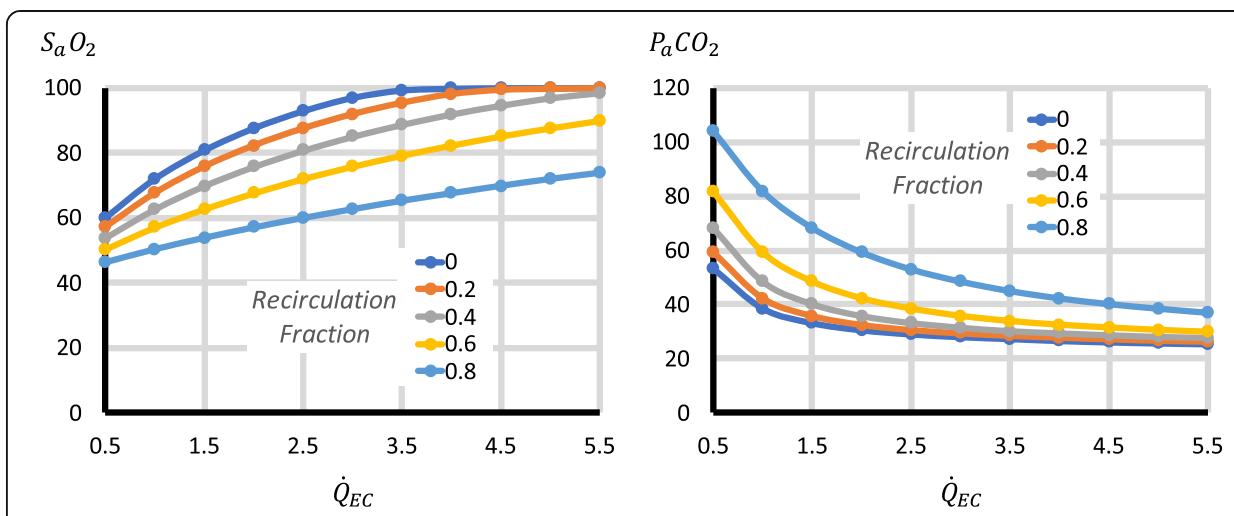

Fig. 7 The effect of recirculation. $\frac{\dot{Q}_{S}}{\dot{Q}_{T}}$ is held constant at 0.7. With increasing recirculation, $\mathrm{P}_{\mathrm{a}} \mathrm{CO}_{2}$ rises and $\mathrm{S}_{\mathrm{a}} \mathrm{O}_{2}$ falls. Recirculation has more effect on $\mathrm{P}_{a} \mathrm{CO}_{2}$ when $\dot{Q}_{E C}$ is low

provides guidance to the clinician who wishes to control $\mathrm{P}_{\mathrm{a}} \mathrm{CO}_{2}$. $\dot{V}_{\text {SWEEP }}$ can be adjusted by changing the sweep gas flow rate on the oxygenator, and $\dot{V} \mathrm{CO}_{2}$ can be modified with sedation, paralysis and temperature control. $\frac{\dot{Q}_{S}}{\dot{Q}_{T}}$ is more dependent on the underlying lung pathology. Manipulation of $\mathrm{Hb}, \mathrm{F}_{\mathrm{I}} \mathrm{O}_{2}, F_{O X Y} \mathrm{O}_{2}$ and $\dot{Q}_{T}$ will have minimal effect on $\mathrm{P}_{\mathrm{a}} \mathrm{CO}_{2}$.

While ultra-protective ventilation strategies have been recommended for patients on vv-ECMO [19], practices vary widely between centres [20]. The effect of different ventilation strategies was not studied with the model. Unless $\frac{\dot{Q}_{S}}{\dot{Q}_{T}}$ is 1 , differences in minute ventilation that modify $\dot{V}_{A}$ will directly affect $\mathrm{P}_{\mathrm{a}} \mathrm{CO}_{2}$. Differences in positive end expiratory pressure may affect lung recruitment and alter $\frac{\dot{Q}_{S}}{\dot{Q}_{T}}$.

Schmidt et al. observed in vivo the determinants of oxygenation and decarboxylation during vv-ECMO in ten adult patients with respiratory failure [5]. When $\dot{Q}_{E C}$ was reduced from a baseline of $5.8 \pm 0.8 \mathrm{l} / \mathrm{min}$ by $40 \%$ to $2.4 \pm 0.3 \mathrm{l} / \mathrm{min}, \mathrm{P}_{\mathrm{a}} \mathrm{O}_{2}$ and $\mathrm{S}_{\mathrm{a}} \mathrm{O}_{2}$ fell, but there was no change in $\mathrm{P}_{\mathrm{a}} \mathrm{CO}_{2}$. When maintaining $\dot{Q}_{E C}$ at baseline values, reducing $F_{O X Y} \mathrm{O}_{2}$ from 1.0 to 0.4 resulted in a fall in $\mathrm{P}_{\mathrm{a}} \mathrm{O}_{2}$ and $\mathrm{S}_{\mathrm{a}} \mathrm{O}_{2}$, but no change in $\mathrm{P}_{\mathrm{a}} \mathrm{CO}_{2}$. In contrast, when the sweep gas flow rate reduced from 10 to $2 \mathrm{l} / \mathrm{min}, \mathrm{P}_{\mathrm{a}} \mathrm{O}_{2}$ did not change, and $\mathrm{P}_{\mathrm{a}} \mathrm{CO}_{2}$ rose. In the three patients given a red blood cell transfusion, there was a rise in $\mathrm{P}_{\mathrm{a}} \mathrm{O}_{2}$ (no data were presented for $\mathrm{P}_{\mathrm{a}} \mathrm{CO}_{2}$ ). These findings are consistent with the predictions of the physiology made by the mathematical model, providing clinical validation of the model.

The model has several limitations. Gas exchange in the oxygenator was modelled as perfusion limited, which is not always the case with a real oxygenator. When the surface area of a membrane lung is low and blood flow is high, $\mathrm{CO}_{2}$ elimination is limited by diffusion. As the surface area increases, diffusion limitation becomes less important and $\mathrm{CO}_{2}$ elimination becomes predominantly perfusion limited [21]. $\mathrm{O}_{2}$ uptake increases linearly with blood flow in the Quadrox oxygenator, up to the rated maximum $\dot{Q}_{E C}$ of 7 1/min [9], though this is not the case for all oxygenators. The assumption of predominantly perfusion limited gas exchange is unlikely to result in 
major inaccuracy during vv-ECMO, providing a suitable oxygenator is used. Oxygenator performance deteriorates with time, due to deposition of protein and clot formation on the surface exposed to blood, and water accumulation on the surface exposed to gas [22]. With long-term use, the findings of the model may become less applicable as the oxygenator performance deteriorates. Input parameters of the model were treated as independent variables, which is not true in vivo. For example, cardiac output changes in response to anaemia, hypercapnia or hypoxia. $\frac{\dot{Q}_{S}}{\dot{Q}_{T}}$ changes in response to $\mathrm{P}_{\mathrm{pa}} \mathrm{O}_{2}$ which affects pulmonary vascular tone. Despite these limitations, the findings of the model are in keeping with in vivo data [5].

The model does not include a dead space compartment in the oxygenator. Castagna et al. studied oxygenators after several days of vv-ECMO (4.0 days, IQR 2.0-8) and found $\frac{\dot{V}_{D}}{\dot{V}_{T}}$ of $47.8 \pm 15.3$ (mean \pm sd) [22]. This finding fits the clinical observation that the sweep gas flow rate required to maintain normocapnia often gradually increases during an ECMO run. As dead space develops, the same gas transfer across the oxygenator can be maintained by increasing $\dot{V}_{\text {SWEEP }}$.

The findings presented in this paper relate to the ARDS patient with high $\frac{\dot{Q}_{S}}{\dot{Q}_{T}}$, that requires $\dot{Q}_{E C} \geq 2 \mathrm{l} / \mathrm{min}$ to support oxygenation. During extracorporeal $\mathrm{CO}_{2}$ removal, $\dot{Q}_{E C}$ is usually $<2 \mathrm{l} / \mathrm{min}$, and $\dot{Q}_{E C}$ becomes a major determinant of $\mathrm{CO}_{2}$ elimination. Gas exchange across the membranes used for extracorporeal $\mathrm{CO}_{2}$ removal is often limited by incomplete diffusion [21], and this may be exacerbated by the high gas sweep to blood flow ratios that are used to facilitate $\mathrm{CO}_{2}$ removal. A range of techniques have been tried to enhance $\mathrm{CO}_{2}$ removal including using carbonic anhydrase [23], acidification of blood or dialysate [24] and electrodialysis [25]. Further modelling of the factors affecting gas exchange during extracorporeal $\mathrm{CO}_{2}$ removal may prove enlightening.

Consider a scenario where a patient that was stable on ECMO becomes febrile and hypoxic. As the metabolic rate increased with the fever, the sweep gas was increased to maintain normal $\mathrm{P}_{\mathrm{a}} \mathrm{CO}_{2}$. To correct the hypoxia, it is planned to increase $\dot{Q}_{E C}$ from 2.5 to $5 \mathrm{l} / \mathrm{min}$. What should be done with $\dot{V}_{\text {SWEEP }}$ to maintain normal $\mathrm{P}_{\mathrm{a}} \mathrm{CO}_{2}$ ? The model predicts that with normal $\dot{V} \mathrm{CO}_{2}$, changes in $\dot{Q}_{E C}$ would have minimal effect on $\mathrm{P}_{\mathrm{a}} \mathrm{CO}_{2}$ providing $\dot{Q}_{E C}$ is $>2 \mathrm{l} / \mathrm{m}$, so no change in $\dot{V}_{\text {SWEEP }}$ would be required. This is consistent with standard teaching on managing ECMO. However, in this scenario, $\dot{V} \mathrm{CO}_{2}$ is elevated, and the model predicts that increasing $\dot{Q}_{E C}$ will increase $\mathrm{CO}_{2}$ elimination, so the clinician will need to reduce $\dot{V}_{\text {SWEEP }}$ to maintain a normal $\mathrm{P}_{\mathrm{a}} \mathrm{CO}_{2}$. Another scenario where the model may be of assistance to the clinician is when a patient is anaemic on ECMO and requires blood transfusion to maintain adequate oxygenation. What should be done with $\dot{V}_{\text {SWEEP }}$ to maintain normal $\mathrm{P}_{\mathrm{a}} \mathrm{CO}_{2}$ ? Despite the importance of $\mathrm{Hb}$ in $\mathrm{CO}_{2}$ transport in blood, the model predicts that during vv-ECMO, even large changes in $\mathrm{Hb}$ will have minimal effect on $\mathrm{P}_{\mathrm{a}} \mathrm{CO}_{2}$. No change in $\dot{V}_{\text {SWEEP }}$ is required. The emphasis of this paper has been on $\mathrm{CO}_{2}$ exchange during vv-ECMO, but the model is equally applicable to $\mathrm{O}_{2}$ exchange. It supports clinical decision making by improving the clinician's understanding of vv-ECMO physiology. 


\section{Conclusion}

A mathematical model of gas exchange during vv-ECMO, incorporating $\mathrm{O}_{2}, \mathrm{CO}_{2}$ and $\mathrm{N}_{2}$ exchange, was developed. The results of the model were consistent with previous mathematical models that only examined $\mathrm{O}_{2}$ exchange and predict the findings of clinical studies. The main determinants of $\mathrm{P}_{\mathrm{a}} \mathrm{CO}_{2}$ during vv-ECMO were lung $\frac{\dot{Q}_{S}}{\dot{Q}_{T}}$, metabolic $\mathrm{CO}_{2}$ production, $\dot{V}_{\text {SWEEP }}$ and extracorporeal circuit recirculation.

\section{Additional files}

Additional file 1: Description of the ECMO model and the mathematical equations on which it is based. (PDF $205 \mathrm{~kb})$

Additional file 2: This file contains the output of the program for the scenarios modelled. Each worksheet contains the output for a single scenario. (XLSX $236 \mathrm{~kb}$ )

Additional file 3: This file contains the output of the program for the validation against Zanella's model. Each worksheet contains the output of the program and graphs generated from this output, corresponding to one of Zanella's figures. (XLSX $155 \mathrm{~kb}$ )

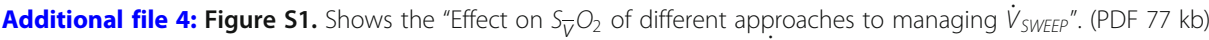

Additional file 5: Figure S2. Shows the "Effect of recirculation at high $\frac{\dot{Q}_{5}}{\dot{Q}}$. (PDF $67 \mathrm{~kb}$ )

Additional file 6: Figure S3. Shows the "Effect on $\mathrm{P}_{\mathrm{a}} \mathrm{CO}_{2}$ of $\mathrm{Hb}$ ". (PDF $74 \mathrm{~kb}$ )

Additional file 7: Figure S4. Shows the "Effect of $\mathrm{F}_{1} \mathrm{O}_{2}$ on $\mathrm{P}_{\mathrm{a}} \mathrm{CO}_{2}$ ". (PDF $74 \mathrm{~kb}$ )

Additional file 8: Figure S5. Shows the "Effect of $\mathrm{F}_{\mathrm{Ox}} \mathrm{O}_{2}$ on $\mathrm{PaCO}_{2}$ ". (PDF $76 \mathrm{~kb}$ )

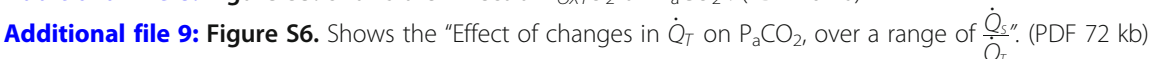

Additional file 10: Figure S7. Shows the "Sensitivity to which lung model is used". (PDF 88 kb)

\section{Abbreviations}

$\dot{\mathrm{V}} \mathrm{O}_{2}: \mathrm{O}_{2}$ consumption in $\mathrm{ml} \mathrm{STPD} / \mathrm{min} ; \dot{V} \mathrm{CO}_{2}: \mathrm{CO}_{2}$ production in $\mathrm{ml} \mathrm{STPD} / \mathrm{min} ; \mathrm{C}_{\mathrm{a}} \mathrm{O}_{2}$ : Arterial oxygen content in $\mathrm{ml} / \mathrm{dl}$ blood STPD; $\mathrm{S}_{a} \mathrm{O}_{2}$ : Arterial oxygen saturation; $\mathrm{P}_{\mathrm{a}} \mathrm{CO}_{2}$ : Arterial partial pressure of $\mathrm{CO}_{2}$ in mm $\mathrm{Hg}_{2} \mathrm{P}_{\mathrm{a}} \mathrm{O}_{2}$ : Arterial partial pressure of $\mathrm{O}_{2}$ in $\mathrm{mm} \mathrm{Hg}$; $\dot{Q}_{\mathrm{EC}}$ : Blood flow to the extracorporeal circuit in I/min; $\dot{Q}_{T}$ : Cardiac output in I/min; $\dot{Q}_{p}$ : Blood flow to the lung compartment in I/min; $\dot{Q}_{S}$ : Pulmonary shunt blood flow in I/min; $\frac{V_{D}}{V_{T}}$ : Dead space to tidal volume ratio; $\dot{V}_{D}$ : Dead space ventilation of the lung in I/min BTPS; $\dot{V}_{A}$ : Expired alveolar ventilation of the lung in I/min BTPS;

$\dot{V}_{E}$ : Expired minute ventilation of the lung in I/min BTPS; $\frac{\dot{V}_{A}}{\dot{Q}_{L}}$ Expired ventilation perfusion ratio of the lung; $\frac{\dot{Q}_{R C}}{\dot{Q}_{E C}}$ Fraction of $\dot{Q}_{E C}$ that is recirculated to the extracorporeal circuit; $\mathrm{F}_{1} \mathrm{O}_{2}$ : Inspired oxygen fraction of the lung; $F_{O x Y} \mathrm{O}_{2}$ : Inspired oxygen fraction of the oxygenator; cvoz: Mixed venous oxygen content in $\mathrm{ml} / \mathrm{dl}$ blood STPD; $\mathrm{S}_{\bar{V}} \mathrm{O}_{2}$ : Mixed venous oxygen saturation; $\mathrm{P}_{\mathrm{pa}} \mathrm{CO}_{2}$ : Partial pressure of $\mathrm{CO}_{2}$ in the pulmonary artery; $\mathrm{P}_{\mathrm{pa}} \mathrm{N}_{2}$ : Partial pressure of $\mathrm{N}_{2}$ in the pulmonary artery; $\mathrm{P}_{\mathrm{pa}} \mathrm{O}_{2}$ : Partial pressure of $\mathrm{O}_{2}$ in the pulmonary artery; $\frac{\dot{Q}_{S}}{\dot{Q}_{T}}$ : Pulmonary shunt fraction; $\frac{\dot{V}_{D}}{\dot{V}_{T}}$ : Ratio of dead space ventilation to total ventilation; $\frac{\dot{Q}_{S E C}}{\dot{Q}_{E C}}$ Shunt fraction of the extracorporeal circuit; $\dot{V}_{\text {SWEEP }}$ : Sweep gas flow rate to the oxygenator in I/min ATPD; ARDS: Acute respiratory distress syndrome; ATPD: Ambient temperature and pressure dry; BTPS: Body temperature and pressure saturated; DP50: Factor that accounts for shifts in the $\mathrm{O}_{2}$ dissociation curve due to changes in 2,3 diphosphoglycerate; Hb: Haemoglobin in g/dl; Hct: Haematocrit; STPD: Standard temperature and pressure dry; temp: Body temperature in ${ }^{\circ} \mathrm{C} ; \mathrm{w}$-ECMO: Venovenous extracorporeal membrane oxygenation

\section{Availability of data and materials}

The datasets supporting the conclusions of this article are included within the article and its additional files. See the file "Explanation of supplementary material.docx" for details.

\section{Authors' contributions}

CJ and DC developed the mathematical model. CJ did the programming, ran the simulations, formatted the results and wrote the paper. CJ, DC and KS revised the manuscript and intellectual content. All authors gave their approval to the final version of the manuscript to be published. All authors read and approved the final manuscript.

\section{Authors' information}

CJ is Director of Intensive Care at Princess Alexandra Hospital, and Associate Professor at University of Queensland. Qualifications are MB, ChB, PhD, FCICM, FANZCA. DC is Senior Staff Specialist in Intensive Care at Princess Alexandra Hospital, Adjunct Professor at Queensland University of Technology, and Associate Professor at University of Queensland. Qualifications are MB, BS, PhD, FCICM, FANZCA. KS is Senior Staff Specialist in Intensive Care at The Prince Charles Hospital. Qualifications are MB, BS, PhD, FCICM. 


\section{Consent for publication}

"Not applicable"

\section{Competing interests}

The authors declare that they have no competing interests.

\section{Publisher's Note}

Springer Nature remains neutral with regard to jurisdictional claims in published maps and institutional affiliations.

\section{Author details}

'Discipline of Anaesthesiology Critical Care, University of Queensland, Ned Hanlon Building, Royal Brisbane and Women's Hospital, Herston, QLD 4006, Australia. ${ }^{2}$ Department of Intensive Care, Princess Alexandra Hospital, 199 Ipswich Rd, Woolloongabba, QLD 4102, Australia. ${ }^{3}$ Adult Intensive Care Services, The Prince Charles Hospital, Rode Rd., Chermside, Brisbane, QLD 4032, Australia. ${ }^{4}$ Science and Engineering Faculty, Queensland University of Technology, 2 George St, Brisbane, QLD 4000, Australia. ${ }^{5}$ Critical Care Research Group and the Centre of Research Excellence for Advanced Cardiorespiratory Therapies Improving Organ Support (ACTIONS), Brisbane, QLD, Australia.

Received: 15 March 2018 Accepted: 9 July 2018

Published online: 09 August 2018

\section{References}

1. Thiagarajan RR, Barbaro RP, Rycus PT, McMullan DM, Conrad SA, Fortenberry JD, Paden ML (2017) Extracorporeal life support organization registry international report 2016. ASAIO J 63:60-67

2. Brogan TV, Lequier L, Lorusso R, MacLaren G, Peek G (2017) Physiology of extracorporeal life support. In: Bartlett $\mathrm{RH}$, Conrad SA (eds) Extracorporeal life support: the ELSO red book, 5th edn. Extracorporeal Life Support Organization, Ann Arbor

3. Helmerhorst HJ, Schultz MJ, van der Voort PH, de Jonge E, van Westerloo DJ (2015) Bench-to-bedside review: the effects of hyperoxia during critical illness. Crit Care 19:284. https://doi.org/10.1186/s13054-015-0996-4

4. Eastwood GM, Young PJ, Bellomo R (2014) The impact of oxygen and carbon dioxide management on outcome after cardiac arrest. Curr Opin Crit Care 20:266-272

5. Schmidt M, Tachon G, Devilliers C, Muller G, Hekimian G, Brechot N, Merceron S, Luyt CE, Trouillet JL, Chastre J, Leprince P, Combes A (2013) Blood oxygenation and decarboxylation determinants during venovenous ECMO for respiratory failure in adults. Intensive Care Med 39:838-846

6. Glynn P, Unudurthi SD, Hund TJ (2014) Mathematical modeling of physiological systems: an essential tool for discovery. Life Sci 111:1-5

7. Yeager T, Roy S (2017) Evolution of gas permeable membranes for extracorporeal membrane oxygenation. Artif Organs 41:700-709

8. Hany Hazfiza M, Ahmad Khairi Abdul W, Fathiah Mohamed Z (2017) Mathematical modelling of carbon dioxide exchange in hollow fiber membrane oxygenator. IOP Conference Series: Materials Science and Engineering 210. https://doi.org/10.1088/1757-899X/210/1/012003

9. Tabesh H, Amoabediny G, Poorkhalil A, Khachab A, Kashefi A, Mottaghy K (2012) A theoretical model for evaluation of the design of a hollow-fiber membrane oxygenator. J Artif Organs 15:347-356

10. Spinelli E, Bartlett RH (2014) Relationship between hemoglobin concentration and extracorporeal blood flow as determinants of oxygen delivery during venovenous extracorporeal membrane oxygenation: a mathematical model. ASAIO J 60:688-693

11. Zanella A, Salerno D, Scaravilli V, Giani M, Castagna L, Magni F, Carlesso E, Cadringher P, Bombino M, Grasselli G, Patroniti N, Pesenti A (2016) A mathematical model of oxygenation during venovenous extracorporeal membrane oxygenation support. J Crit Care 36:178-186

12. Riley RL, Cournand A (1949) Ideal alveolar air and the analysis of ventilation-perfusion relationships in the lungs. J Appl Physiol 1:825-847

13. Kelman GR (1966) Digital computer subroutine for the conversion of oxygen tension into saturation. J Appl Physiol 21:1375-1376

14. Kelman GR (1966) Calculation of certain indices of cardio-pulmonary function, using a digital computer. Respir Physiol 1:335-343

15. Kelman GR (1967) Digital computer procedure for the conversion of PCO2 into blood CO2 content. Respir Physio 3:111-115

16. West JB, Wagner PD (1977) Pulmonary gas exchange. In: West JB (ed) Bioengineering Aspects of the Lung. edn. Marcel Decker, New York

17. Gattinoni L, Marini JJ, Pesenti A, Quintel M, Mancebo J, Brochard L (2016) The "baby lung" became an adult. Intensive Care Med 42:663-673

18. Seear M, Anderson B, Hall R, Hui H (1995) Mathematical model of oxygen transport: a teaching aid for normal physiology adaptable to extracorporeal oxygenation circuits. Am J Phys 268:\$32-\$39

19. Schmidt M, Pellegrino V, Combes A, Scheinkestel C, Cooper DJ, Hodgson C (2014) Mechanical ventilation during extracorporeal membrane oxygenation. Crit Care 18:203

20. Marhong JD, Telesnicki T, Munshi L, Del Sorbo L, Detsky M, Fan E (2014) Mechanical ventilation during extracorporeal membrane oxygenation. An international survey. Ann Am Thorac Soc 11:956-961

21. Karagiannidis C, Strassmann S, Brodie D, Ritter P, Larsson A, Borchardt R, Windisch W (2017) Impact of membrane lung surface area and blood flow on extracorporeal CO2 removal during severe respiratory acidosis. Intensive Care Med Exp 5:34 
22. Castagna L, Zanella A, Scaravilli V, Magni F, Deab SA, Introna M, Mojoli F, Grasselli G, Pesenti A, Patroniti N (2015) Effects on membrane lung gas exchange of an intermittent high gas flow recruitment maneuver: preliminary data in veno-venous ECMO patients. J Artif Organs 18:213-219

23. Arazawa DT, Kimmel JD, Finn MC, Federspiel WJ (2015) Acidic sweep gas with carbonic anhydrase coated hollow fiber membranes synergistically accelerates CO2 removal from blood. Acta Biomater 25:143-149

24. Zanella A, Mangili P, Giani M, Redaelli S, Scaravilli V, Castagna L, Sosio S, Pirrone F, Albertini M, Patroniti N, Pesenti A (2014) Extracorporeal carbon dioxide removal through ventilation of acidified dialysate: an experimental study. J Heart Lung Transplant 33:536-541

25. Zanella A, Castagna L, Abd El Aziz El Sayed Deab S, Scaravilli V, Ferlicca D, Magni F, Giani M, Salerno D, Casati M, Pesenti A (2016) Extracorporeal CO2 removal by respiratory Electrodialysis: an in vitro study. ASAIO J 62: 143-149

Submit your manuscript to a SpringerOpen ${ }^{\circ}$ journal and benefit from:

- Convenient online submission

- Rigorous peer review

- Open access: articles freely available online

- High visibility within the field

- Retaining the copyright to your article

Submit your next manuscript at $\boldsymbol{\nabla}$ springeropen.com 